\title{
Counselling Nigerian Women for Education and Development Through Information and Communication Technology (ICT)
}

\author{
Stella Ngozi Nduka-Ozo \\ Ebonyi State University, Abakaliki-Nigeria
}

\author{
Doi:10.5901/mjss.2013.v4n8p113
}

\begin{abstract}
This paper on counselling Nigerian women for education and development through information and communication technology highlights the ways and means women could get education even when they cannot afford to enroll into schools. Although the responsibilities left for the Nigerian women are enormous, leaving them little or no time for education yet women have been called the weaker sex a result of their low capacity. Professionals in the field have conceptualized education from various perspectives, but the common agreement by authors is that women education has been to a large extent sacrificed on the alter of discrimination. Since any development cannot be complete without the involvement of women, they need education to be appropriately empowered for development, which is a process of change to a better, more advanced and highly organized situation, This can be enhanced by the use of the information and communication technology (ICT). With the introduction of information and communication technology women now have better chance of accessing information from any part of the world to develop them. Counselling is a helping relationship equipped with information on any field of human endevours. With the right counsel, therefore, any woman can now have free access to as much knowledge, education and enlightenment as she wants for maximum development.
\end{abstract}

\section{Introduction}

Counselling has been defined by Nwachukwu (1996) as a relationship between a professionally trained competent counsellor and an individual seeking help in gaining greater self understanding and improved decision making and behaviour changing skills for problem resolution and developmental growth. People need counselling to have better self-understanding and improved decision making skills, values and perception with its concomitant ways of making choices. Iwuama (2000) also observed that using the client centred counselling approach is very useful for those who have need for positive self-concept and selfawareness and hence able to make right choices. Continuing, he maintained that with empathic support from the counsellor and with the necessary clues the client could be helped to explore and understand self from a better perspective, which could help him/her to develop a positive self-concept and have self realization; hence be able to take more rational decisions of life. Counselling can also be seen as a helping relationship in which a client who has problem gets help from a professional who has the necessary skills in problem solving. A counsellor could be the one to help the client who is confused to re-orient her values and ways of perceiving things in other to make the right choices through understanding of the true position of things. This could be applicable in the use of information and communication technology by those Nigerian women who are either prevented from going to school, drop out to take care of their families or had only basic education thereby sensitizing them to the need to go further.

Women in Nigeria have been called all sorts of names including the 'weaker sex', but are they really the weaker sex? A typical Nigerian woman wakes up at 5 o'clock in the morning with a baby strapped on her back and begins to clean-up the house, prepare the breakfast, and get the older children ready for school before preparing for work herself, where she has the privilege of being allowed to work. Meanwhile, the husband is still fast asleep, only to get up at 7 o'clock and demand for hot water to bathe before proceeding 
to the table for his meal, and off he goes to work. In the rural areas of Nigeria, a mother with a bundle of firewood on her head and a child strapped on her back is a common sight. Such a woman would have done some farm work before collecting the fire wood. She then goes home to break some of the big logs with an axe, before cooking for the family. In Germany over 70 percent of mothers feel stressed. About 51 percent have complaints involving the spine and intervertebral disks; over a third is constantly tired and despondent, while 30 percent suffer from headaches or migraines from work over-load (Awake 2002).

A very pathetic illustration of the work load on women in Nigeria was given by Akanu (2007), in which she showed a typical woman saddled with various responsibilities like nursing children, going out to look for daily bread, fetching fire wood and water, cooking, washing clothes and dishes and serving the food among others. The tasks connected with the home are the fundamental tasks of humanity, if a mother does not do her duty, there will be no next generation but must she die doing so?. With even a limited education, many mothers make a lot of difference in the society, how much more when they are proficient in different careers. The saying is true that when you educate women, you educate a nation. Women tend to be more sensitive to issues of affiliation, inclusion, loneliness and acceptance. They have greater tenderness, understanding and better control of emotions. Women are hardworking, dependable and obedient and when given the chance, are accountable in handling positions of trust. Their role in the survival and continuity of any society is certainly not under contention. What has remained an issue of serious concern is that in spite of the acknowledged role women play in nation building and development; various societies like Nigeria have continued to treat them as second class citizens.

\section{Women education in Nigeria}

Education has been variously conceptualized. Fafunwa (1974) saw it as the aggregate of all the processes by which a child or young adult develops the abilities, attitudes and other forms of behaviour which are of positive value to the society in which he lives. Peters (1980) viewed education as the transmission of what is worthwhile to those who become committed to it, Chauhan (1981) saw it as shaping of behaviour or modification of the behaviour of the individual for adequate adjustment in the society; while Ukeje (1991) declared that it is the only potent instrument for social reconstruction, Maduabum (2002) concluded that education is an aggregate of all the processes by means of which a person develops abilities, attitudes and forms of behaviour that enables him/her to live effectively and efficiently in the present society so that he/she may be able to advance or improve it.

The implication of these definitions is that there must be a positive and total development of the behaviour and values of the individual in relation to their environment; and education aids the development processes; which is a life long process, but must be started early enough. Any nation, therefore, that seeks development, relevance, and global recognition cannot afford to neglect education of its citizens, including women. The truth of the matter is that before the 90's in Nigeria the girl child had lower schooling opportunity. During the buoyant economic era, the oil boom of the mid 1970s, Nigeria recorded significant increase in female graduates compared to their male counterparts. But female education as Fafunwa (1974) observed is generally skewed towards subjects considered to be of least resistance, higher competition and in lower demand, excluding them from their interests abilities and capabilities which are the three indices of career choice (Nduka-Ozo, 2009).

In a study carried out by Uwalaka (2011) on impact of women education in national development in Aba North Local Government Area of Abia State, she found out certain factors responsible for lack of education for women which include: parents inclination to educate males first, harsh economic conditions, get rich quick syndrome which sees education as time consuming and early marriage. A similar study by Eze (2012) on factors affecting female education in Ohaukwu Local Government Area of Ebonyi State, showed similar findings. She listed: cultural beliefs, early marriage, poor economic status of parents and poor parental attitude towards female education as factors that contributed to lack of or low female education. Another 
study by Nnubia (2012) on women abuse and neglect, saw the two concepts are challenges to women education. She observed that women abuse and neglect are social-cultural problems which are wide spread in the Nigerian society and serious impediments to women education.

Nzewi (1990) viewed neglect as including deprivation of access to social contact and resources necessary for one's normal development as member a society and excessive or inappropriate demands on the person. Corroborating, Ugwu (2001) asserted that women neglect include all acts of omission or denial of the basic rights and needs of woman, which also impairs her well being. This involves the absence of genuine efforts to create conditions that will enable the women to develop maximally. Women neglect on the other hand is seen by Ugwu (2001) as all intentional acts that hamper the physical, emotional, moral, social, educational, economic and political development of a woman like battering, starvation, fatal poisoning, mutilation, rape, suppression and circumcision which result in female vesico virginal fistula (VVF).

\section{Women Education and Development}

Nnubia (2012) observed that the UNESCO report revealed that $66 \%$ or two thirds of the world's population approximating one billion illiterates were females, while two thirds of the 300 million children who did not have access to formal schooling worldwide were females. Earlier report by UNESCO (1995) had indicated that 26 million African girls were out of school, with a projection that would increase to 36 million by the end of the year 2000. With particular reference to Nigeria the report indicated that $31 \%$ of Nigerian women can read and write while the literate population of the male is $54 \%$. The statistical trends over the years have shown poor enrolment figures all levels of education for females particularly in the rural area. The reason for this trend as shown in this paper is the society's preference for male children, early marriage, teenage pregnancy and religious and cultural prejudices.

The issue of early marriage needs special mention in this paper because in most Nigerian societies the culture permits parent to arrange marriages for their daughters even when they are still in their childhood period. As observed by Ebigbo (1999) the Islamic northern Nigerian societies urge their girl children to get married before their second menstruation which could be between $12-15$ years of age. He further noted that mothers willfully send their daughters to the streets where they could meet prospective suitors. One can, therefore, imagine what the educational level of such a girl, who will be expected to start bearing children for the husband, will be. Even in the southern part of Nigeria the average age for marriage is 18 years for girls while males still get married at 40 for the first time. Such a man by this time is fully made both educationally and economically and may in some cases look for sweet sixteen as wife. Such a mis-match can only lead to a master/servant relationship with the husband taking all the decisions, including keeping his wife at home to avoid her becoming wiser.

"Study after study has shown that there is no effective development strategy in which women do not play a central role. When women are fully involved, the benefits can be seen immediately: families are healthier and better fed; their income, savings and reinvestment go up; and what is true of families is also true of communities and, in the long run, of whole countries". (Annan 2003)

Countries all over the world as observed by Egwu (2007) have been acknowledging the logic that no full development can be attained without utilizing the potentials of the women population that constitute the substantial fraction of the total population. This truth underscored the Federal Government's promulgation of Decree no. 11 of 1995 establishing the National Centre for Women Development in 1992 in Abuja. Continuing Egwu lamented that in the past, Nigerian women, and other women from the developing countries of the world, despite their noble roles in the development of the society, have not always been well treated due to low or no education. They have indeed been denied equal rights to basic education, economic advancement, always alienated in matters of governance through discriminatory and often times harmful traditional practices that have deliberately humiliated them. 
Development is a process of change to a better, more advanced and highly organized conditions (Osim 2007). Development is not only the provision of infrastructure, but a gradual process of advancement which include mental, physical, economical and social condition of a people. It is on this premise that students are given scholarship, workers are given in-service training; other forms of support are given in order to empower individuals for their development and advancement. Development is seen as a continuous process, and as long as women exist, their contributions to the growth of the nation will continue if given the required education. They have been involved in all facets of development in spite of the apparent neglect, lack of appreciation of their efforts and inhibitions by cultural and religious beliefs. With the introduction of information and communication technology any woman can have free access to as much knowledge, education and enlightenment as she wants.

\section{Information and communication technology (ITC) as it relates to women education and development}

Information and communication technologies (ICTs) has been defined by Okenwa (2000) as the various modern devices and applications, such as cable, satellite, the online network and telemetric applications that facilitate the circulation of ideas and create a link between data and human beings. Amadi (2011 p.142) noted that "Information and communication technologies (ICTs) are simply communication gadgets, equipments or facilities that improve the manner in which message is shared, relayed, disseminated, preserved and recalled for meaningful communication purposes. It is also the soft and hardware innovations for normalizing and enhancing interaction in the society". Information and communication technology include films, slides, video tapes, audio tapes, radio and television programmes, computer, CD rom and internet which are used as E-learning facilities in schools. The Internet according to Encarta (2009) is composed of many interconnected computer networks. Each network may link tens, hundreds, or even thousands of computers, enabling them to share information and processing power.

The Internet has made it possible for people all over the world to communicate with one another effectively and inexpensively. Unlike traditional broadcasting media, such as radio and television, the Internet does not have a centralized distribution system. Instead, an individual who has Internet access can communicate directly with anyone else on the Internet, post information for general consumption, retrieve information, use distant applications and services, or buy and sell products. This media can now make education easier for women, the use of information and communication technologies (ICTs) could enhance their efficiency. Any woman who still feels discriminated against, even with the access to ICTs is merely 'crying wolf'. This is where the Counsellor comes in, to sensitize such women who are still lagging to wake up. We now live in the world of ICTs. As McWilliams (in Nkwocha, 2004: 13) observed "those who don't bother about computer don't bother about the future and the future is where we are going to spend the rest of our lives." The Counsellor is equipped with information that will help any woman to better herself even in her bed room.

\section{Conclusion}

Counselling has been seen to give empathic support and the necessary clues the client needs to explore and understand self from a better perspective, which could help him/her to develop a positive self-concept and have self realization of potentials; hence be able to take more rational decisions in life. The potentials of Nigerian women, to a great extent, have remained unutilized and under-utilized as a result of subjugation by certain cultural practices hindering women from achieving optimum self development. Women education has been grossly neglected in many parts of the country for reasons ranging from economic hardship to cultural discrimination. Women education should be encouraged to empower them for the development of families and the nation. The few women who have made it to the top like Margaret Thatcher of blessed memory, the 
'iron lady' of Britain, Imelda Marcos of Philippines, Indira Gandhi of India, Golda Meir of Israel, Valentina Tereshkova of Russia (the first woman in space) and Prof Dora Akunyili of Nigeria have all proved their mettle. Egwu (2005) opined that International Women's Day Celebration should transcend the romanticisation of the female gender to the celebration of women as strategic vehicles for the socio-economic and political development of the society.

With the advent of Information and Communication Technologies (ICTS) women now stand a better chance of improving themselves through the services available to them. As observed earlier, the Internet has made it possible for people all over the world to communicate with one another effectively and in a less expensive way. Any individual who has Internet access can communicate directly with anyone else and get all information required. In order words as they say in Igbo language in Nigeria "Ihe di woro ogori agba na ahia" meaning that some of the things a husband deny his wife can still be bought in the market by the wife, if she has the right counsel.

\section{Recommendations}

Based on the fore-gone discussions on Counselling Nigerian women for education and development through Information and Communication Technologies (ICTs) the following recommendations are hereby given:

That there should be functional Adult Education Centres (with ICT facilities) in every Nigerian community aimed at functional literacy and numeracy for women could not go to school as a result of sociocultural problems.

Guidance Counsellors should also be posted to such centres in order to help in personalizing the needs of such adult learner with a view to helping them achieve self- understanding and optimum realization of their potentials.

There should be legal education aimed at enlightening women on their fundamental human rights and the need to seek redress when their rights are infringed.

The issue of family planning education should be highlighted to help women understand the need to have only the number of children they can adequately take care of considering the present sophistication of modern society.

\section{References}

Akanu, C.C. (2007). Role of Women. In Women Development Platform. Abakaliki: Women Development Centre.

Amadi, N.A. (2011), Uses and Impact of ICT in the Print Media, in, Ike S. Ndolo (Ed). Contemporary issues in Communication and Society. Enugu: Rhyce Kerex Publishers.

Anambra State Ministry of Women Affairs and Social Development. (2007).

Gender Mainstreaming as a Tool for Sustainable Grass root Development. Nimo: Rex Charles and Patrick Ltd. (1 Edition)

Annan, K. (2003), The Role of Mothers as Educators. In Awake. New York: Watchtower Bible and Tract Society.

Awake, (2002), Motherhood in Various Lands. New York: Watchtower Bible and Tract Society.

Chauhan S.S., (1981), Advanced education psychology. New Delhi: Vikas Publishing House.

Egwu, S.O. (2005). A Challenge to my Generation: Selected Speeches. Enugu: Fegno Printing \& Packaging Company Ltd.

Eze, C.E. (2012), Factors affecting female Education in Ohaukwu Local Government Area. An Unpublished B.Ed project presented to the Department of Educational Foundations, Faculty of Education, Ebonyi State University, Abakaliki.

Fafunwa, B.A. (1974). History of Education in Nigeria. London: George Allen And Unwin.

Hannan, C. (2008). From Concepts to Action: Gender Mainstreaming in Operational Activities. Paper presented at the UNDP supported workshop at Grace Court Hotel and Suites, Abakaliki.

Haruna, I.I. (2007). Gender, Politics and the Law. In Women Development Platform. Abakaliki: Women Development Centre. 
Iwuama, B.C. (2000), The Client-centred Theory, In Counselling Theories: A Synoptic Survey. B.C. Iwuama, F.J.Nwachukwu and F.U. Obimba (Ed). Owerri: Joe Mankpa's Publishers.

Maduabum, M.A. (2002), UBE Implementation: A challenge for the New Millennium. In S.N. Agwu (ed). A Handbook for Beginning Teachers in Nigeria. Enugu: Pan Afric Publishers.

Nduka-Ozo, S.N. (2009). Making the Right Career Choice, being a paper presented at a one day Seminar to Students at St. Patrick's Catholic Church, Abakaliki.

Nkwocha, J. (2004), Computer application and Public Relations. In J. Nkwocha (Ed.) Digital Public Relations: New Techniques Management. Lagos: Zoom Lens Publication. Vol.1.1 (13-27).

Nnubia, V.A. (2012), Women abuse and neglect:: A challenge to women education.. being a seminar presented at the PGDE programme of the Faculty of Education, Ebonyi State University, Abakalikil

Nwachukwu, F.J. (1996), The Basic Concept of Guidance and Counselling in Nwachukwu F.J. and Ugwuegbulam C.N. (ed.) Guidance and Counselling, An Introductory Survey. Benin: Barloz Publishers.

Okenwa, N.S. (2001), The Mass Media Uses and Regulations. Enugu: Bismark Publications.

Osim, V. (2007). Ebonyi Women and National Development. In Women Development Platform. Abakaliki: Women Development Centre.

Peters, R.S. (1980), Ethics and Education. London: Macmillan.

Ugwu, A.B.C. (2001), Education for special target groups in Nigeria. Enugu: Ceeta Limited.

Ukeje, B.O. (1991), The Education of Teachers for new social order. Kaduna: Nigerian Teacher.

Uwalaka, D.U. (2011), Impact of women education in National Development In Aba North Local Government Area. An unpublished B.Ed project presented to the Department of Educational Foundations, Faculty of Education, Ebonyi State University, Abakaliki.

Uzoezie, C.E. (2007). Advocacy for Gender Equality. In Gender Mainstreaming as a Tool for Sustainable Grass root Development. Nimo: Rex Charles and Patrick Ltd. (1 ${ }^{\text {st }}$ Edition) 